\title{
Task technology fit in online transaction through apps
}

Naser Valaei, Sunway University Business School, Sunway University, Malaysia. Email:naserv@sunway.edu.my

S.R. Nikhashemi, Sunway University Business School, Sunway University, Malaysia. Email: farhadn@sunway.edu.my

Prof. Hwang Ha Jin, Sunway University Business School, Sunway University, Malaysia.

Email: hjhwang@sunway.edu.my

\begin{abstract}
The purpose of this chapter is to examine what aspects of task-technology characteristics are more relevant to fit, satisfaction, and continuance intention of using apps in mobile banking transactions. Applying SEM approach to a sample of 250 Malaysians, the findings of this study imply that task characteristic of transactionbased apps is more relevant than technology characteristics. The results suggest that degree of fit is highly associated with mobile apps' user satisfaction. Furthermore, the higher the degree of fit, the higher is the continuance intention to use apps for online transactions. Surprisingly, the findings show that the task characteristics are not relevant to continuous intention to use apps for online transactions.
\end{abstract}

Keywords: Task technology fit, task characteristics, technology characteristics, mobile apps, online transactions

\section{Introduction}

Recent years, the rapid development of applications has evolved extensively and electronic devices are being smarter and smaller. Nowadays, companies are struggling to provide their services on the go through apps to not lag behind their competitors. Mobile application, as a new channel, has become the necessity for humanbeings (Rezaei et al., 2017). Consumer orientation toward using the online banking has changed. Study by Sangle and Awasthi (2011) indicate that mobile banking is crucial after understanding the importance of the concurrent use of various channels of financial and banking companies. Customers prefer to do transactions, transfer funds, pay their bills, and see their statements on the go (Wannemacher and L'Hostis, 2015, Nikhashemi et al., 2017), and they favor a 24/7 banking service.

Mobile banking is defined as the behaviour of making a financial transaction through mobile devices such as tablets and smartphones. Consumer behaviour has influenced increasingly by mobile banking (Taghavi-Fard and Torabi, 2010). Rahmani et al. (2012) indicate that wireless communication channel and affordable 
Internet data plans by telecommunication providers let the customers to move toward mobile banking. Previous research shows that mobile banking allow banks to reduce their costs, stay competitive, and retend of customers (Laukkanen et al., 2008).

Goodhue and Thompson (1995) claim that if the technology achieves a good fit, the performance will be greater fulfilling user needs. Task-technology fit will be higher when the functionality of technology fits the needs of customers. According to Lin and Wang (2006), customer satisfaction is the key element to determine the continuous intention of customers to use a technology. If the apps meet the consumer need, they will be satisfied and continue in using the apps (Rezaei and Valaei, 2017). Research is scarce on what aspects of task-technology fit impacts on satisfaction and continuance intention to use apps in mobile banking. However, this research tries to bridge this gap by answering the following question:

- What aspects of task-technology fit are more relevant to fit, satisfaction, and continuance intention of using apps in mobile banking transactions?

\section{A brief literature review}

Task-technology fit is a model used to determine the concepts of fit and utilisation. Task-technology fit theory focuses on the representation of problem and tasks which must have suitable fit to solve the problem. Task-technology fit is used to determine the intersection between a right technological tool and the performing task (Goodhue and Thompson, 1995). According to Goodhue and Thompson (1995), there are three key elements in Task-technology Fit model, where "task characteristics" and "technology characteristics" will fit together to form the "task-technology fit".

Task characteristics is defined as a behaviour performed by individuals to satisfy their information needs by changing inputs to outputs (Goodhue and Thompson, 1995). Relying on Schrier et al. (2010), a completion of a task is linked to the individual performance and the increasing of the task can enhance the effectiveness and efficiency.

H1: Task characteristic is positively related to level of fit in apps mobile banking.

According to task-technology fit theory, when the task fits the customers need and improves their performance, then the customers will adopt the information system (Gebauer et al., 2010). Technology characteristics are the attributes of the tools users use when carrying out specific tasks and they include software, hardware and support 
services (Goodhue and Thompson, 1995). When technology is utilised, chances are that it has a good fit (Schrier et al., 2010). However, it is likely that this scenario applies in apps channel as well.

H2: Technology characteristic is positively related to level of fit in apps mobile banking.

Customer satisfaction is the "fit" between the advantage of using a system and the need of customers (Goodhue, 1998). According to Goodhue (1998), satisfaction is the most appropriate way to measure the usefulness of systems. Furthermore, the most appropriate way to measure "task-technology fit" would be the feeling of users about the systems and how the system satisfaction meet the task needs (Goodhue, 1998).

Financial institutions are growing fast nowadays and they have transformed from traditional systems to more digital systems and the nature of a relationship between customers, products and services is a significant element of the banking industry (Mohsan et al., 2011).

H3: There is a positive relationship between task characteristics and user satisfaction in apps mobile banking.

H4: There is a positive relationship between technology characteristics and user satisfaction in apps mobile banking.

H5: There is a positive relationship between fit and user satisfaction in apps mobile banking.

The evaluation of quality perceptions and services can determine the continuous usage of Internet by customers (Ribbink et al., 2004). The success of the IT products and services depends on the continuous intention of individuals (Parthasarathy and Bhattacherjee, 1998, Karahanna et al., 1999). Bhattacherjee (2001) indicates that while the expectation of the information system is satisfied, then the customers will continue using the information system. However, once customers have loyalty towards apps then they will continue to use mobile banking apps. Figure 1 schematically depics all the research hypotheses.

H6: There is a positive relationship between task characteristics and continuance intention of using apps in mobile banking.

H7: There is a positive relationship between technology characteristics and continuance intention of using apps in mobile banking. 
H8: There is a positive relationship between fit and continuance intention of using apps in mobile banking.

H9: There is a positive relationship between satisfaction and continuance intention of using apps in mobile banking.

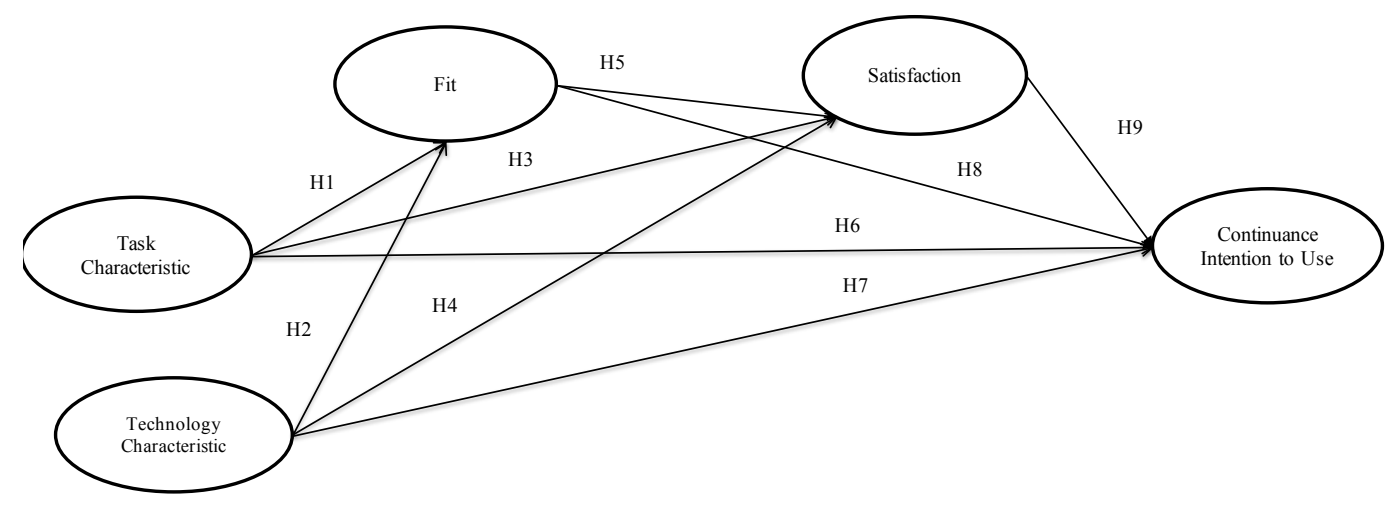

Figure 1: Research model

\section{Methodology}

This study uses convenience sampling approach and to measure the variables, measurement items are adopted from prior established researches as a methodological norm in measuring latent variables (Westland, 2015, Valaei et al., 2017). Prior to data analysis, we applied several steps to ensure that any possible bias is avoided. For instance, Harman's one factor test (Podsakoff et al., 2003) shows that there is no common method bias, as no single factor accounts for more than $50 \%$ of the total variance (the results of principal component analysis with no rotation showed a total variance of $45.3 \%$ ). We addressed the missing values through expectationmaximization algorithm (EMA) (Little, 1988) applying SPSS software (Version 20). Finally, a-priori sample size calculator for structural equation models (Soper, 2015) showed that sample size of 250 is adequate, as the recommended minimum sample size for an anticipated effect size of 0.3 and desired statistical power of 0.95 is 223 .

The questionnaire was developed from previous established studies as a methodological norm. Data is collected from university students to test the measurement and structural models using partial least squares (PLS), a variance-based structural equation modeling approach (Valaei and Jiroudi, 2016). A seven level 
Likert scale was used within which 1 denotes "strongly disagree" and 7 denotes "strongly agree". Table 1 shows the sample information. To analyze the models, SmartPLS software version 3.2.4 (Ringle et al., 2015) is used.

Table 1: Sample information $(N=250)$

\begin{tabular}{|c|c|c|c|}
\hline & & Frequency & Percentage \\
\hline \multirow[t]{2}{*}{ Gender } & Male & 113 & 45.2 \\
\hline & Female & 137 & 54.8 \\
\hline \multirow[t]{5}{*}{ Age } & $18-24$ years old & 205 & 82.0 \\
\hline & $25-34$ years old & 38 & 15.2 \\
\hline & $35-44$ years old & 5 & 2.0 \\
\hline & $45-54$ years old & 1 & 0.4 \\
\hline & $55-64$ years old & 1 & 0.4 \\
\hline \multirow[t]{4}{*}{ Race } & Chinese & 221 & 88.4 \\
\hline & Malay & 8 & 3.2 \\
\hline & Indian & 9 & 3.6 \\
\hline & Others & 12 & 4.8 \\
\hline \multirow{4}{*}{$\begin{array}{l}\text { Monthly } \\
\text { Expenses }\end{array}$} & Below 2000 & 187 & 74.8 \\
\hline & $2001-4000$ & 47 & 18.8 \\
\hline & $4001-6000$ & 9 & 3.6 \\
\hline & More than 6001 & 7 & 2.8 \\
\hline
\end{tabular}

\section{Results}

\section{Measurement model assessment}

Before assessing the structural model, the researcher needs to ensure the validity and reliability of measurement model. To assess the measurement model, Cronbach's alpha, rho_A values, composite reliability, AVE (average variance extracted) and discriminant validity are examined. As tabulated in Table 2, all factor loadings are higher than the threshold of 0.7 and the AVEs are higher than 0.5. All values of rho_A (as a new measure of construct reliability), composite reliability, and Cronbach's alpha are acceptable (more than 0.7). Figure 2 schematically shows the 
measurement model within which the Task characteristic $\rightarrow$ Continuance intention to use apps has the lowest path coefficient.

Table 2: Reliability and validity

\begin{tabular}{|c|c|c|c|c|c|c|}
\hline Research Construct & Item & Loading & Rho_A & AVE & $\begin{array}{l}\text { Composite } \\
\text { Reliability }\end{array}$ & $\begin{array}{c}\text { Cronbach } \\
\text { Alpha }\end{array}$ \\
\hline \multirow[t]{3}{*}{ Task characteristics } & TaskCh1 & 0.856 & 0.852 & 0.767 & 0.908 & 0.848 \\
\hline & TaskCh2 & 0.891 & & & & \\
\hline & TaskCh3 & 0.880 & & & & \\
\hline \multirow[t]{6}{*}{ Technology characteristics } & TechCh1 & 0.780 & 0.854 & 0.575 & 0.890 & 0.852 \\
\hline & TechCh2 & 0.803 & & & & \\
\hline & TechCh3 & 0.733 & & & & \\
\hline & TechCh4 & 0.737 & & & & \\
\hline & TechCh5 & 0.775 & & & & \\
\hline & TechCh6 & 0.720 & & & & \\
\hline \multirow[t]{5}{*}{ Fit } & Fit1 & 0.841 & 0.896 & 0.698 & 0.920 & 0.891 \\
\hline & Fit2 & 0.869 & & & & \\
\hline & Fit3 & 0.771 & & & & \\
\hline & Fit4 & 0.854 & & & & \\
\hline & Fit5 & 0.838 & & & & \\
\hline \multirow[t]{3}{*}{ User satisfaction } & Sat1 & 0.916 & 0.899 & 0.831 & 0.937 & 0.898 \\
\hline & Sat2 & 0.898 & & & & \\
\hline & Sat3 & 0.921 & & & & \\
\hline \multirow{3}{*}{$\begin{array}{l}\text { Continuance intention to } \\
\text { use apps }\end{array}$} & CI1 & 0.914 & 0.900 & 0.831 & 0.936 & 0.898 \\
\hline & CI2 & 0.902 & & & & \\
\hline & CI3 & 0.917 & & & & \\
\hline
\end{tabular}

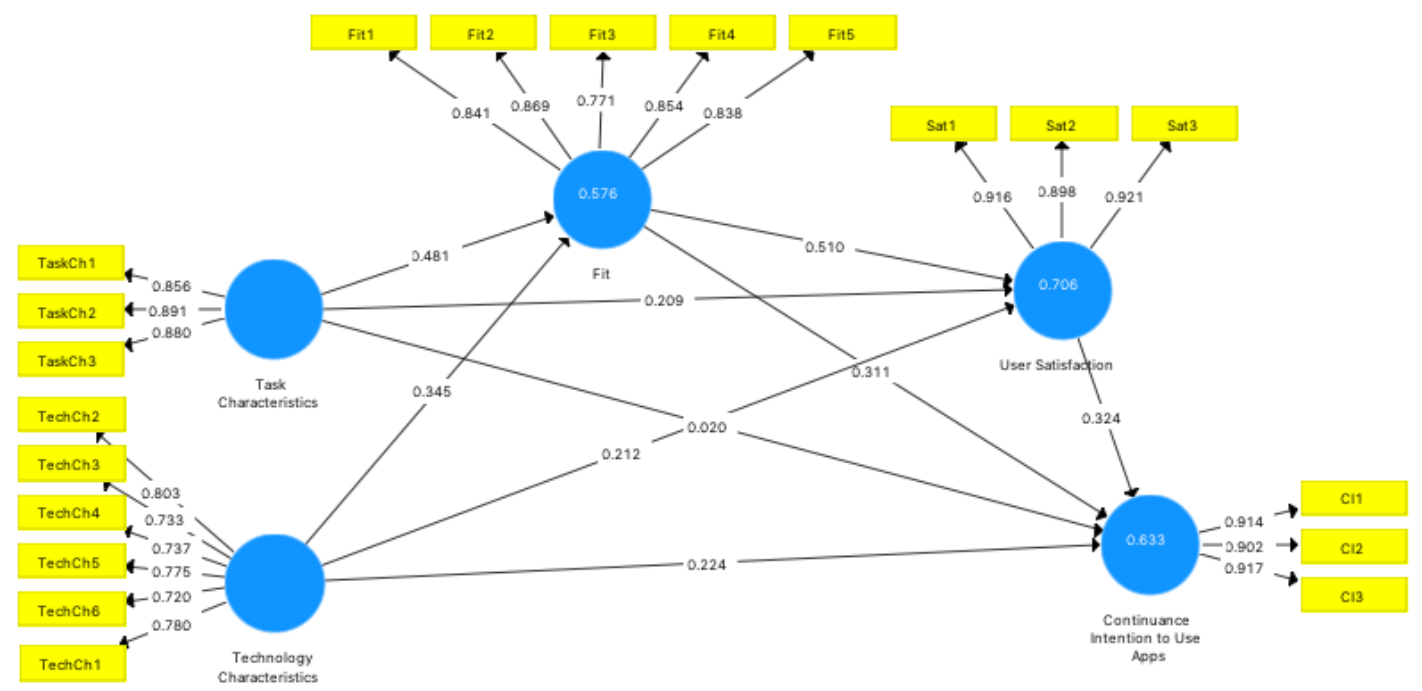

Figure 2: Results of measurement model 
To assess the discriminant validity, Table 3 shows the Fornell-Larcker criterion (Fornell and Larcker, 1981). The results show that this criterion is met and the square roots of AVEs (diagonals in Table 3) are higher than the correlations between the constructs.

Table 3: Fornell-Larcker criterion

\begin{tabular}{|c|c|c|c|c|c|}
\hline Constructs & $\begin{array}{l}\text { Continuance } \\
\text { Intention to } \\
\text { Use Apps } \\
\end{array}$ & Fit & $\begin{array}{c}\text { Task } \\
\text { Character- } \\
\text { istics } \\
\end{array}$ & $\begin{array}{c}\text { Technology } \\
\text { Character- } \\
\text { istics }\end{array}$ & $\begin{array}{c}\text { User } \\
\text { Satisfaction }\end{array}$ \\
\hline $\begin{array}{l}\text { Continuance } \\
\text { Intention to Use } \\
\text { Apps }\end{array}$ & 0.911 & & & & \\
\hline Fit & 0.736 & 0.835 & & & \\
\hline $\begin{array}{l}\text { Task } \\
\text { Characteristics }\end{array}$ & 0.627 & 0.716 & 0.876 & & \\
\hline $\begin{array}{l}\text { Technology } \\
\text { Characteristics }\end{array}$ & 0.672 & 0.672 & 0.680 & 0.759 & \\
\hline User Satisfaction & 0.744 & 0.802 & 0.718 & 0.696 & 0.912 \\
\hline
\end{tabular}

Another measure of discriminant validity is assessing the cross loading criterion. According to Table 4, all loadings of each construct (bold values in Table 4) are higher than the cross loadings of other measurement items of other constructs. However, this criterion is met.

Table 4: Cross loadings criterion

\begin{tabular}{|c|c|c|c|c|c|}
\hline Items & $\begin{array}{l}\text { Continuance } \\
\text { Intention to } \\
\text { Use Apps }\end{array}$ & Fit & $\begin{array}{l}\text { Task } \\
\text { Characteristics }\end{array}$ & $\begin{array}{l}\text { Technology } \\
\text { Characteristics }\end{array}$ & $\begin{array}{l}\text { User } \\
\text { Satisfaction }\end{array}$ \\
\hline CI1 & 0.914 & 0.629 & 0.522 & 0.577 & 0.658 \\
\hline CI2 & 0.902 & 0.688 & 0.595 & 0.615 & 0.673 \\
\hline CI3 & 0.917 & 0.691 & 0.595 & 0.642 & 0.701 \\
\hline Fit1 & 0.620 & 0.841 & 0.640 & 0.636 & 0.689 \\
\hline Fit2 & 0.642 & 0.869 & 0.651 & 0.588 & 0.705 \\
\hline Fit3 & 0.504 & 0.771 & 0.499 & 0.456 & 0.560 \\
\hline Fit4 & 0.653 & 0.854 & 0.587 & 0.551 & 0.695 \\
\hline Fit5 & 0.638 & 0.838 & 0.598 & 0.559 & 0.685 \\
\hline Sat1 & 0.708 & 0.754 & 0.659 & 0.683 & 0.916 \\
\hline Sat2 & 0.654 & 0.745 & 0.671 & 0.582 & 0.898 \\
\hline Sat3 & 0.670 & 0.692 & 0.632 & 0.637 & 0.921 \\
\hline TaskCh1 & 0.517 & 0.568 & 0.856 & 0.554 & 0.581 \\
\hline
\end{tabular}




\begin{tabular}{llllll}
\hline TaskCh2 & 0.563 & 0.649 & $\mathbf{0 . 8 9 1}$ & 0.588 & 0.661 \\
TaskCh3 & 0.566 & 0.658 & $\mathbf{0 . 8 8 0}$ & 0.641 & 0.639 \\
TechCh2 & 0.550 & 0.538 & 0.554 & $\mathbf{0 . 8 0 3}$ & 0.552 \\
TechCh3 & 0.475 & 0.488 & 0.524 & $\mathbf{0 . 7 3 3}$ & 0.486 \\
TechCh4 & 0.514 & 0.488 & 0.464 & $\mathbf{0 . 7 3 7}$ & 0.468 \\
TechCh5 & 0.545 & 0.554 & 0.541 & $\mathbf{0 . 7 7 5}$ & 0.577 \\
TechCh6 & 0.484 & 0.480 & 0.434 & $\mathbf{0 . 7 2 0}$ & 0.502 \\
TechCh1 & 0.486 & 0.504 & 0.570 & $\mathbf{0 . 7 8 0}$ & 0.574 \\
\hline
\end{tabular}

The last discriminant validity criterion is Heterotrait-monotrait ratio . Shown in Table 5, all values are lower than the threshold of 0.9. Therefore, the discriminant validity of the constructs is met and the measurement model is reliable and valid.

Table 5: Heterotrait-monotrait ratio

\begin{tabular}{|c|c|c|c|c|}
\hline Constructs & $\begin{array}{c}\text { Continuance } \\
\text { Intention to } \\
\text { Use Apps } \\
\end{array}$ & Fit & $\begin{array}{c}\text { Task } \\
\text { Characteristics }\end{array}$ & $\begin{array}{c}\text { Technology } \\
\text { Characteristics }\end{array}$ \\
\hline Fit & 0.817 & & & \\
\hline Task Characteristics & 0.716 & 0.817 & & \\
\hline $\begin{array}{l}\text { Technology } \\
\text { Characteristics }\end{array}$ & 0.766 & 0.766 & 0.797 & \\
\hline User Satisfaction & 0.826 & 0.892 & 0.820 & 0.793 \\
\hline
\end{tabular}

Note: The threshold value for Heterotrait-monotrait ratio is 0.9 (Teo et al., 2008).

\section{Structural model assessment}

The results of Table 6 show that the model has high predictive relevancy and the $R^{2}$ and $Q^{2}$ values have large effect size. The results of hypothesis testing (tabulated in Table 7 and schematically depicted in Figure 3) show that all hypotheses are supported except H6 (Task Characteristics $\rightarrow$ Continuance Intention to Use Apps with a weak path coefficient of 0.02 and insignificant T-value of 0.277 ). The highest significant path coefficients are received for the Fit $\rightarrow$ User Satisfaction and Task Characteristics $\rightarrow$ Fit relationships with value of 0.51 and 0.481 respectively. 
Table 6: $R^{2}$ and $Q^{2}$ values

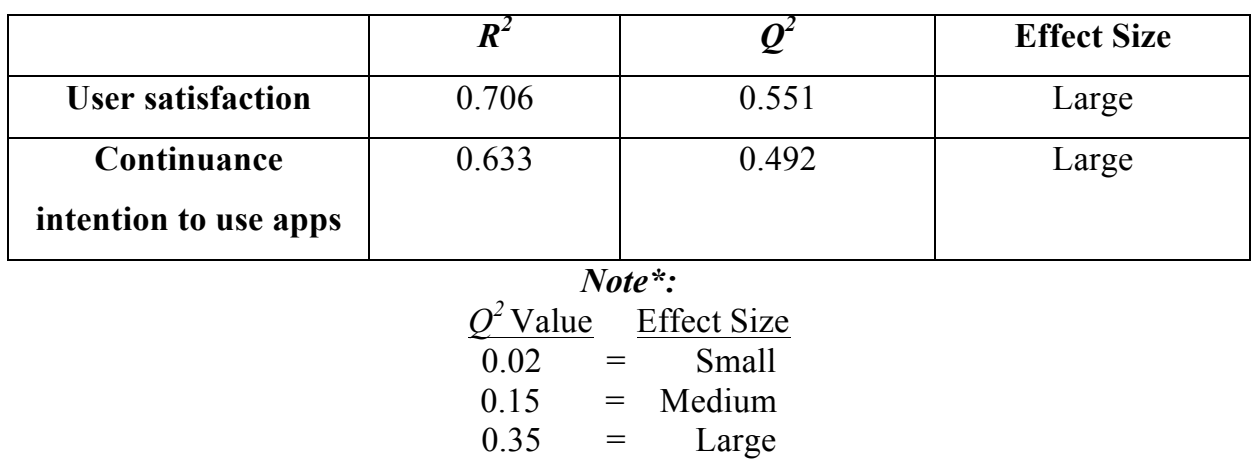

Table 7: Results of hypothesis testing

\begin{tabular}{|c|c|c|c|c|c|}
\hline Hypothesis & Path & $\begin{array}{c}\text { Path } \\
\text { coefficient }\end{array}$ & $\begin{array}{c}\text { Standard } \\
\text { Error }\end{array}$ & T-Statistics & Decision \\
\hline H1 & Task Characteristics -> Fit & 0.481 & 0.066 & $7.345^{*}$ & Supported \\
\hline $\mathrm{H} 2$ & Technology Characteristics -> Fit & 0.345 & 0.074 & $4.633^{*}$ & Supported \\
\hline $\mathrm{H} 3$ & Task Characteristics -> User Satisfaction & 0.209 & 0.052 & $4.019 *$ & Supported \\
\hline $\mathrm{H} 4$ & $\begin{array}{c}\text { Technology Characteristics -> User } \\
\text { Satisfaction }\end{array}$ & 0.212 & 0.061 & $3.45^{*}$ & Supported \\
\hline H5 & Fit $->$ User Satisfaction & 0.51 & 0.064 & $8.03 *$ & Supported \\
\hline H6 & $\begin{array}{c}\text { Task Characteristics -> Continuance } \\
\text { Intention to Use Apps }\end{array}$ & 0.02 & 0.073 & 0.277 & Not Supported \\
\hline $\mathrm{H} 7$ & $\begin{array}{c}\text { Technology Characteristics -> } \\
\text { Continuance Intention to Use Apps }\end{array}$ & 0.224 & 0.062 & $3.611^{*}$ & Supported \\
\hline H8 & Fit $->$ Continuance Intention to Use Apps & 0.311 & 0.075 & $4.169^{*}$ & Supported \\
\hline H9 & $\begin{array}{c}\text { User Satisfaction -> Continuance Intention } \\
\text { to Use Apps }\end{array}$ & 0.324 & 0.074 & $4.405^{*}$ & Supported \\
\hline
\end{tabular}

Note: ${ }^{*} \mathrm{p}<0.01$ 


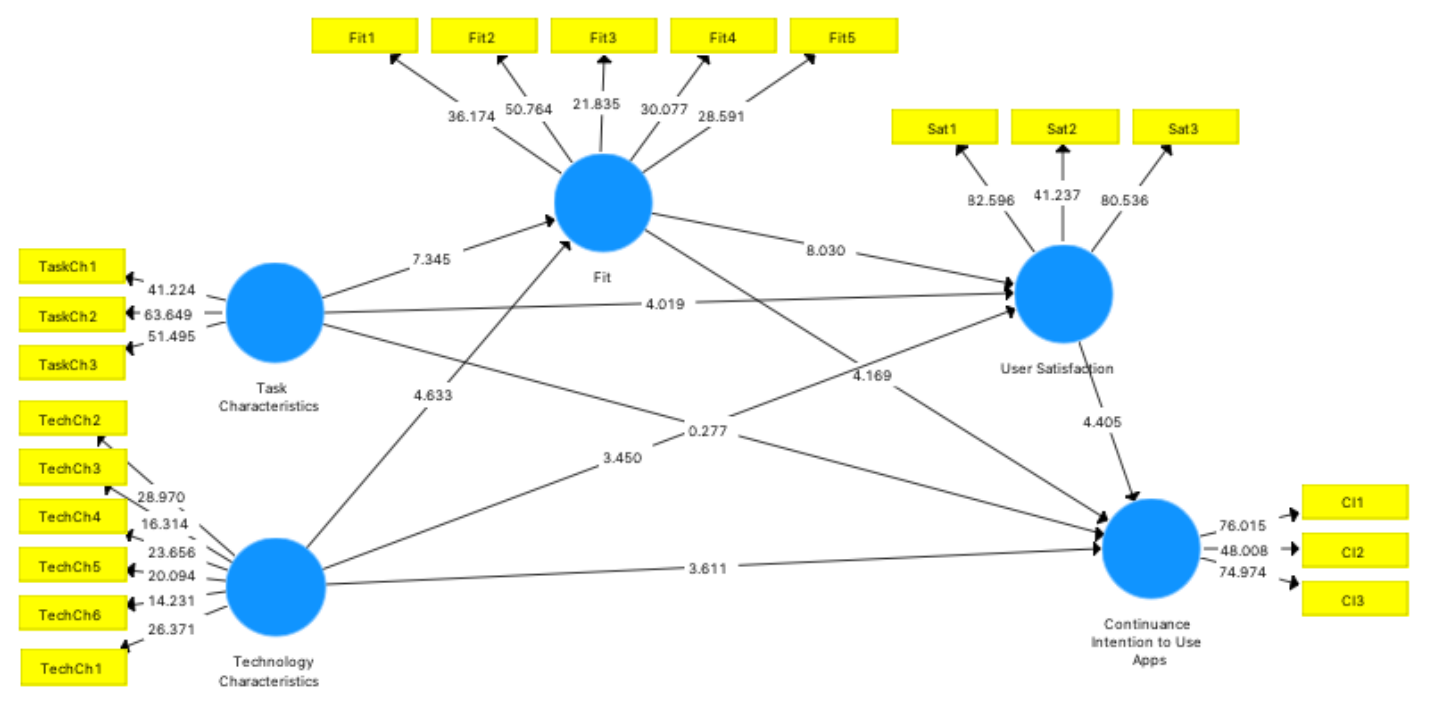

Figure 3: Bootstrapping results

\section{Discussion and conclusion}

Task characteristics are closely related to the fit (Hollingsworth, 2015). An appropriate fit for the technology device-specific activity could be achieved by the combination of the relevant task characteristics. The findings of this study imply that task characteristic of transaction-based apps (path coefficient of 0.481 ) is more relevant than technology characteristic.

Task-technology fit can be affected by the functionality of technology. The performance of an app can be influenced by the fit between technologies (Trice and Treacy, 1988). Due to the convenience mobile devices provide, degree of fit becomes important. The findings suggest that degree of fit is highly associated with mobile apps' user satisfaction (path coefficient of 0.51). According to Goodhue (1998), satisfaction is the most appropriate way to measure the usefulness of systems.

A poor fit decreases the intention to adopt a new technology (Lee et al., 2005, Liang et al., 2007). The results show that the higher the degree of fit, the higher is the continuance intention to use apps for online transactions (path coefficient of 0.311). Furthermore, continuous intention of information systems is resorted to the satisfaction of the consumers (Larsen et al., 2009). Delone and McLean (2003) indicate that the determination of nett benefit and customer loyalty can be assumed by the customer satisfaction in IS success model. Aligned with previous researches (Zeithaml et al., 1996, Szymanski and Henard, 2001, Heitmann et al., 2007), this 
study finds a positive relationship between customer satisfaction and continuous intention to use apps.

Surprisingly, the results indicate that the task characteristics are not relevant to continuous intention to use apps for online transactions (path coefficient $=0.02$ and $\mathrm{T}$-value $=0.277)$. Further research is required to examine other factors associated with the fit and the extent to which they may impact on user satisfaction and continuous intention to use apps for online transactions.

\section{References}

Bhattacherjee, A. (2001), "Understanding information systems continuance: an expectationconfirmation model", MIS quarterly, Vol. 25 No. 3, pp. 351-370.

Delone, W. H. and McLean, E. R. (2003), "The DeLone and McLean model of information systems success: a ten-year update", Journal of management information systems, Vol. 19 No. 4, pp. 9-30.

Fornell, C. and Larcker, D. F. (1981), "Evaluating structural equation models with unobservable variables and measurement error", Journal of Marketing Research, Vol. 18 No. 1 , pp. 39-50.

Gebauer, J., Shaw, M. J. and Gribbins, M. L. (2010), "Task-technology fit for mobile information systems", Journal of Information Technology, Vol. 25 No. 3, pp. 259272.

Goodhue, D. L. (1998), "Development and measurement validity of a task - technology fit instrument for user evaluations of information system", Decision sciences, Vol. 29 No. 1, pp. 105-138.

Goodhue, D. L. and Thompson, R. L. (1995), "Task-technology fit and individual performance", MIS quarterly, Vol. 19 No. 2, pp. 213-236.

Heitmann, M., Lehmann, D. R. and Herrmann, A. (2007), "Choice goal attainment and decision and consumption satisfaction", Journal of marketing research, Vol. 44 No. 2, pp. 234-250.

Hollingsworth, C. L. (2015), "An Examination of Fit and the Use of Mobile Devices for Performing Tasks".

Karahanna, E., Straub, D. W. and Chervany, N. L. (1999), "Information technology adoption across time: a cross-sectional comparison of pre-adoption and post-adoption beliefs", MIS quarterly, pp. 183-213.

Larsen, T. J., Sørebø, A. M. and Sørebø, Ø. (2009), "The role of task-technology fit as users' motivation to continue information system use", Computers in Human Behavior, Vol. 25 No. 3, pp. 778-784.

Laukkanen, P., Sinkkonen, S. and Laukkanen, T. (2008), "Consumer resistance to internet banking: postponers, opponents and rejectors", International journal of bank marketing, Vol. 26 No. 6, pp. 440-455.

Lee, K. C., Lee, S. and Kim, J. S. (2005), "Analysis of mobile commerce performance by using the task-technology fit", Mobile Information Systems, Springer, pp. 135-153.

Liang, T.-P., Huang, C.-W., Yeh, Y.-H. and Lin, B. (2007), "Adoption of mobile technology in business: a fit-viability model", Industrial management \& data systems, Vol. 107 No. 8, pp. 1154-1169.

Lin, H.-H. and Wang, Y.-S. (2006), "An examination of the determinants of customer loyalty in mobile commerce contexts", Information \& management, Vol. 43 No. 3, pp. 271282.

Little, R. J. A. (1988), "Missing-Data Adjustments in Large Surveys", Journal of Business \& Economic Statistics, Vol. 6 No. 3, pp. 287-296. 
Mohsan, F., Nawaz, M. M., Khan, M. S., Shaukat, Z. and Aslam, N. (2011), "Impact of customer satisfaction on customer loyalty and intentions to switch: Evidence from banking sector of Pakistan", International Journal of Business and Social Science, Vol. 2 No. 16.

Nikhashemi, S. R., Valaei, N. and Tarofder, A. K. (2017), "Does Brand Personality and Perceived Product Quality Play a Major Role in Mobile Phone Consumers' Switching Behaviour?", Global Business Review, Vol. 18 No. 3, pp. 108-127.

Parthasarathy, M. and Bhattacherjee, A. (1998), "Understanding post-adoption behavior in the context of online services", Information systems research, Vol. 9 No. 4, pp. 362-379.

Podsakoff, P. M., MacKenzie, S. B., Jeong-Yeon, L. and Podsakoff, N. P. (2003), "Common Method Biases in Behavioral Research: A Critical Review of the Literature and Recommended Remedies", Journal of Applied Psychology, Vol. 88 No. 5, p. 879.

Rahmani, Z., Tahvildari, A., Honarmand, H., Yousefi, H. and Daghighi, M. S. (2012), "Mobile Banking and its Benefits", Oman Chapter of Arabian Journal of Business and Management Review, Vol. 2 No. 5, pp. 38-41.

Rezaei, S. and Valaei, N. (2017), "Crafting experiential value via smartphone apps channel", Marketing Intelligence \& Planning, Vol. 35 No. 5, pp. 688-702.

Rezaei, S., Wee, C. H. and Valaei, N. (2017), "Essential of Apps Marketing Implementation and E-Commerce Strategies: Apps Users' Decision-Making Process", Apps Management and E-Commerce Transactions in Real-Time, IGI Global, pp. 141-158.

Ribbink, D., Van Riel, A. C., Liljander, V. and Streukens, S. (2004), "Comfort your online customer: quality, trust and loyalty on the internet", Managing Service Quality: An International Journal, Vol. 14 No. 6, pp. 446-456.

Ringle, C. M., Wende, S. and Becker, J.-M. (2015), "SmartPLS 3", Boenningstedt: SmartPLS $\mathrm{GmbH}$, http://www.smartpls.com.

Sangle, P. S. and Awasthi, P. (2011), "Consumer's expectations from mobile CRM services: a banking context", Business Process Management Journal, Vol. 17 No. 6, pp. 898918.

Schrier, T., Erdem, M. and Brewer, P. (2010), "Merging task-technology fit and technology acceptance models to assess guest empowerment technology usage in hotels", Journal of Hospitality and Tourism Technology, Vol. 1 No. 3, pp. 201-217.

Soper, D. (2015), "A-priori sample size calculator for Structural Equation Models [Software]".

Szymanski, D. M. and Henard, D. H. (2001), "Customer satisfaction: A meta-analysis of the empirical evidence", Journal of the academy of marketing science, Vol. 29 No. 1, pp. 16-35.

Taghavi-Fard, M. and Torabi, M. (2010), "The Factors Affecting the Adoption of Mobile Banking Services by Customers and Rank Them (Case Study: Bank Tejarat In Tehran, Iran)", Journal Excavations Business Management, Vol. 3, pp. 136-162.

Teo, T. S., Srivastava, S. C. and Jiang, L. (2008), "Trust and electronic government success: An empirical study", Journal of Management Information Systems, Vol. 25 No. 3, pp. 99-132.

Trice, A. W. and Treacy, M. E. (1988), "Utilization as a dependent variable in MIS research", ACM SIGMIS Database, Vol. 19 No. 3-4, pp. 33-41.

Valaei, N. and Jiroudi, S. (2016), "Job satisfaction and job performance in the media industry: a synergistic application of partial least squares path modelling", Asia Pacific Journal of Marketing and Logistics, Vol. 28 No. 5, pp. 984-1014.

Valaei, N., Rezaei, S. and Ismail, W. K. W. (2017), "Examining learning strategies, creativity, and innovation at SMEs using fuzzy set Qualitative Comparative Analysis and PLS path modeling", Journal of Business Research, Vol. 70, pp. 224-233.

Wannemacher, P. and L'Hostis, A. (2015), "Global Mobile Banking Functionality Benchmark", Cambridge.

Westland, J. C. (2015), "Data Collection, Control, and Sample Size", Structural Equation Models, Springer International Publishing, pp. 83-115. 
Zeithaml, V. A., Berry, L. L. and Parasuraman, A. (1996), "The behavioral consequences of service quality", the Journal of Marketing, pp. 31-46. 